\title{
Substance Use Modified Reported Term
}

National Cancer Institute

\section{Source}

National Cancer Institute. Substance Use Modified Reported Term. NCI Thesaurus. Code C83423.

An indication or description of a change in substance usage. 